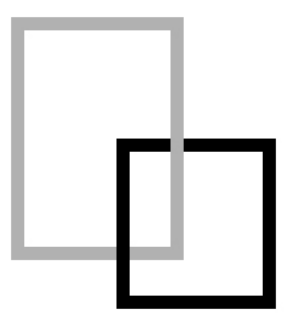

\title{
KOROZJA BIOLOGICZNA I ROŚLINNOŚĆ A TRWAŁA RUINA
}

Biological corrosion and vegetation in the aspect of permanent ruin

\section{Maciej Trochonowicz*, Beata Klimek**, Daniel Lisiecki***}

SUMMARY: The article presents the removal of lichens, algae and fungi algae as mechanisms of biodegradation of structures in well as the procedures for removing unwanted permanent ruins. There are also principles of higher plants are presented.

proceeding in removing undesirable vegetation in these objects. Particular attention was paid to issues related to the diversity of damage caused by biological organisms. Rules for the

KEYWORDS: permanent ruin, biodegradation, biofouling, biocorrosion removal, green removal

\section{WPROWADZENIE}

Za procesy degradacji obiektów zabezpieczonych w postaci trwałej ruiny odpowiedzialnych jest szereg czynników. W większości przypadków procesy te spowodowane są działaniem czynników atmosferycznych (woda, słońce, mróz, wiatr itd.), związane ze zmianami warunków gruntowo wodnych, zmianami w statyce obiektów czy też działalnością człowieka. Odrębną grupą są organizmy żywe zasiedlające i porastające obiekty.

Do grupy organizmów odpowiedzialnych za niszczenie ruin zalicza się głównie rośliny zielone jedno i wieloletnie, drzewa i krzewy, grzyby domowe, grzyby pleśniowe, glony, porosty, mchy oraz owady ${ }^{12}$. W przypadku obiektów pozostawionych w postaci trwałej ruiny negatywne działanie grzybów domowych i owadów ma znaczenie marginalne. Wszystkie pozostałe $\mathrm{z}$ wymienionych w mniejszym lub większym stopniu wpływają na procesy degradacji ruin.

Organizmy te odpowiadają za zjawisko korozji biologicznej, zwaną też biodeterioracją, rozumianą jako zróżnicowane formy niszczenia elementów budowli wywołane działaniem organizmów żywych, tzw. szkodników biologicznych. Wyróżnia się chemiczną asymilacyjną i dysymilacyjną korozję biologiczną. Pierwsza jest najczęstszą formą tego procesu i ma miejsce wówczas, kiedy materiał jest degradowany z racji swej wartości odżywczej. Druga chemiczna dysymilacyjna biodeterioracja (korozja), występuje gdy metabolity drobnoustrojów uszkadzają

* PhD Maciej Trochonowicz, Faculty of Civil Engineering and Architecture, Lublin University of Technology https://orcid.org/0000-0001-7742-7916

** PhD Beata Klimek, Faculty of Civil Engineering and Architecture, Lublin University of Technology https://orcid.org/0000-0002-6967-9766

*** MSc Maciej Trochonowicz, Faculty of Civil Engineering and Architecture, Lublin University of Technology

1 J.A. Eklund, M.E. Young, Biological Growth on Masonry: Identification \&Understanding. Inform. Information of historic building owners. Published by Historic Scotland, January 2013.

2 P. Kozarski, P. Molski, Zagospodarowanie i konserwacja zabytkowych budowli. Towarzystwo Przyjaciół Fortyfikacji, Fortyfikacje tom XIV, Warszawa 2001. 
material ${ }^{3}$.

W przypadku murów chemiczna asymilacyjna korozja nie ma większego znaczenia ze względu na minimalne ilości substancji odżywczych znajdujących się w obiekcie. Ogranicza się jedynie do tych murów gdzie w konstrukcji stosowane były elementy drewniane lub też drewno wykorzystano jako materiał elementów zadaszenia, komunikacji np.: pomosty i punkty widokowe na koronie murów.

Duże znaczenie ma natomiast zjawisko dysymilacyjnej korozji biologicznej. Obrastanie powierzchni materiałów przez organizmy żywe, znane w literaturze przedmiotu jako „biofouling” powodować może szereg niekorzystnych zmian wewnątrz i na powierzchni murów, korozję, pigmentację, wydzielanie toksycznych metabolitów do materiału, uszkodzenia struktury murów na skutek rozrostu systemu korzennego. ${ }^{4}$

Rozwój korozji biologicznej i roślinności powoduje szereg niekorzystnych zmian w ruinie. Zmiany te można podzielić na: techniczne, estetyczne i higieniczno - sanitarne. Skutki techniczne, polegają przede wszystkim na obniżeniu wytrzymałości elementów i konstrukcji, co prowadzi do ich powolnej degradacji. Porażenie korozją biologiczną ma również znaczenie estetyczne, polegają na obniżeniu walorów estetycznych porażonych elementów. Skutki higieniczno - sanitarne, polegające na pogorszeniu stopnia zdrowotności obiektów dla ludzi i zwierząt, w przypadku murów w ruinie nie mają większego znaczenia. ${ }^{5}$

$\mathrm{Z}$ punktu widzenia konserwatorskiego zdecydowanie największe znaczenie dla ruin mają skutki techniczne spowodowane korozją biologiczną i rozwojem roślinności. Dlatego ze względu na techniczny charakter opracowania w dalszej części największy nacisk położony zostanie na wpływ korozji biologicznej na procesy degradacji ruin oraz zasady postępowania przy usuwaniu organizmów powodujących korozję biologiczną i roślinność niepożądaną.

\section{OPIS MECHANIZMÓW NISZCZENIA}

Mechanizm biodegradacji obiektów zabezpieczonych w postaci ruiny jest złożony i zależy od wielu czynników. Do najważniejszych należą: materiał z jakiego został wzniesiony, konstrukcja wysokość i grubość murów, stan wilgotnościowy murów, miejsce w jakim został wzniesiony, rodzaj i wielkość drzew w najbliższym otoczeniu, rodzaje organizmów zasiedlających mury, jakość opieki zarządcy itd. Wszystkie te czynniki w mniejszym lub większym stopniu wpływają na stan techniczny murów związany z niekorzystnym działaniem organizmów powodujących

3 A. B. Strzelczyk, Czynniki niszczace kamienie. Czynniki biologiczne, [w:] Zabytki kamienne i metalowe ich niszczenie i konserwacja profilaktyczna, red. Wiesław Domasłowski. Wydawnictwo Naukowe UMK, Toruń 2011, s.135-157.

4 J. Jasieńko, O. Mierzejewska., K. Hamrol, W. Misztal, Utrwalanie koron murów obiektów historycznych przeznaczonych do ekspozycji w formie trwałej ruiny, „Wiadomości konserwatorskie” nr 30, 2011, s. 117-132.

A. Sieniawska-Kuras, P. Potocki, Przyczyny zniszczeń obiektów budowlanych i elementów architektonicznych. Procesy biologiczne. [w:] Renowacja elementów architektury. Wydawnictwo i handel książkami „KaBe”, Krosno 2012, s. 53-55. 


\section{Korozja biologiczna i roślinność a trwała ruina

korozję biologiczną i obecnością roślinności niepożądanej.

Ze względu na dużą różnorodność uszkodzeń spowodowanych przez organizmy żywe zaproponowano ich podział na trzy grupy. Podział uwzględnia głębokość uszkodzeń oraz przyporządkowuje im grupy organizmów odpowiedzialnych za zniszczenia.

- Grupa I - uszkodzenia powierzchniowe /glony, mszaki, grzyby pleśnie i porosty/ i sukulenty/

- Grupa II- uszkodzenia wgłębne lica i korony /roślinność niska - trawy, byliny

- Grupa III- uszkodzenia konstrukcji /roślinność wysoka - drzewa i krzewy/

\subsection{Grupa I - uszkodzenia powierzchniowe}

Do pierwszej grupy zaliczyć można uszkodzenia spowodowane rozwojem organizmy pozbawione systemów korzennych lub takie u których mają one formę szczątkową. W grupie tej znajdują się glony, porosty, mszaki i grzyby-pleśnie. Organizmy te najczęściej jedynie porastają powierzchnię materiału. Ze względu na różne wymagania środowiskowe (wilgotność, pH podłoża, nasłonecznienie) rozwijać się mogą w różnych miejscach i na większości materiałów występujących w obiektach.

Glony, mszaki i grzyby-pleśnie maja dość duże wymagania co do wilgotności podłoża dlatego też obrastają pas przyziemia murów oraz miejsca zacienione. Największe skupiska tych organizmów obserwowane są na murach od strony północnej. Siedliskiem ich są najczęściej kamienie naturalne i cegła, ale występują również na spoinach i tynkach Ekspansja początkowo powolna z czasem staje się coraz intensywniejsza. Wpływ ma na to możliwość zatrzymywania wilgoci przez glony i mszaki, co prowadzi do jeszcze większego zawilgocenia podłoża w obrębie ich występowania. W konsekwencji na wilgotnych powierzchniach dochodzi do rozwoju kolejnych organizmów. Rozwój ustaje najczęściej przy zmianie warunków wilgotnościowych.

Porosty mają zdecydowanie mniejsze wymagania co do wilgotności podłoża. Są dość odporne na niskie i wysokie temperatury. Dzięki możliwości pobierania wilgoci z powietrza są niezależne od warunków panujących na podłożu Porastają kamienie, cegły, spoiny i tynki. Ich kolorystyka jest bardzo zróżnicowana od jasnych barw do koloru czarnego. Z powodu koloru owocników, często są traktowane jako zabrudzenia.

Powierzchowne uszkodzenia spowodowane przez niektóre gatunki porostów są spowodowane wydzielaniem kwasów i wzrostem komórek w porach kamienia. Glony i grzyby również wydzielają organiczne kwasy, zwłaszcza kwas szczawiowy. Dodatkowo na skutek wrastania strzępków grzybów w pory materiałów może dochodzić do rozluźnienia ich spoistości, a więc zniszczenia warstwy powierzchniowej. Z kolei bakterie siarkowe w procesie metabolicznym powodują powstanie kwasu siarkowego i zapoczątkowują szereg reakcji chemicznych prowadzących $\mathrm{w}$ rezultacie do pękania i kruszenia się materiałów. Bakterie nitryfikacyjne utleniają amoniak /zawarty w wodzie deszczowej, kurzu i sadzy/ do kwasu azotowego, który np. rozpuszcza powierzchniowe warstwy kamieni tworząc charakterystyczne 


\section{${ }^{204}[$}

Maciej Trochonowicz, Beata Klimek, Daniel Lisiecki

nacieki i kratery lub tzw. wykwity śniegowe. ${ }^{6}$
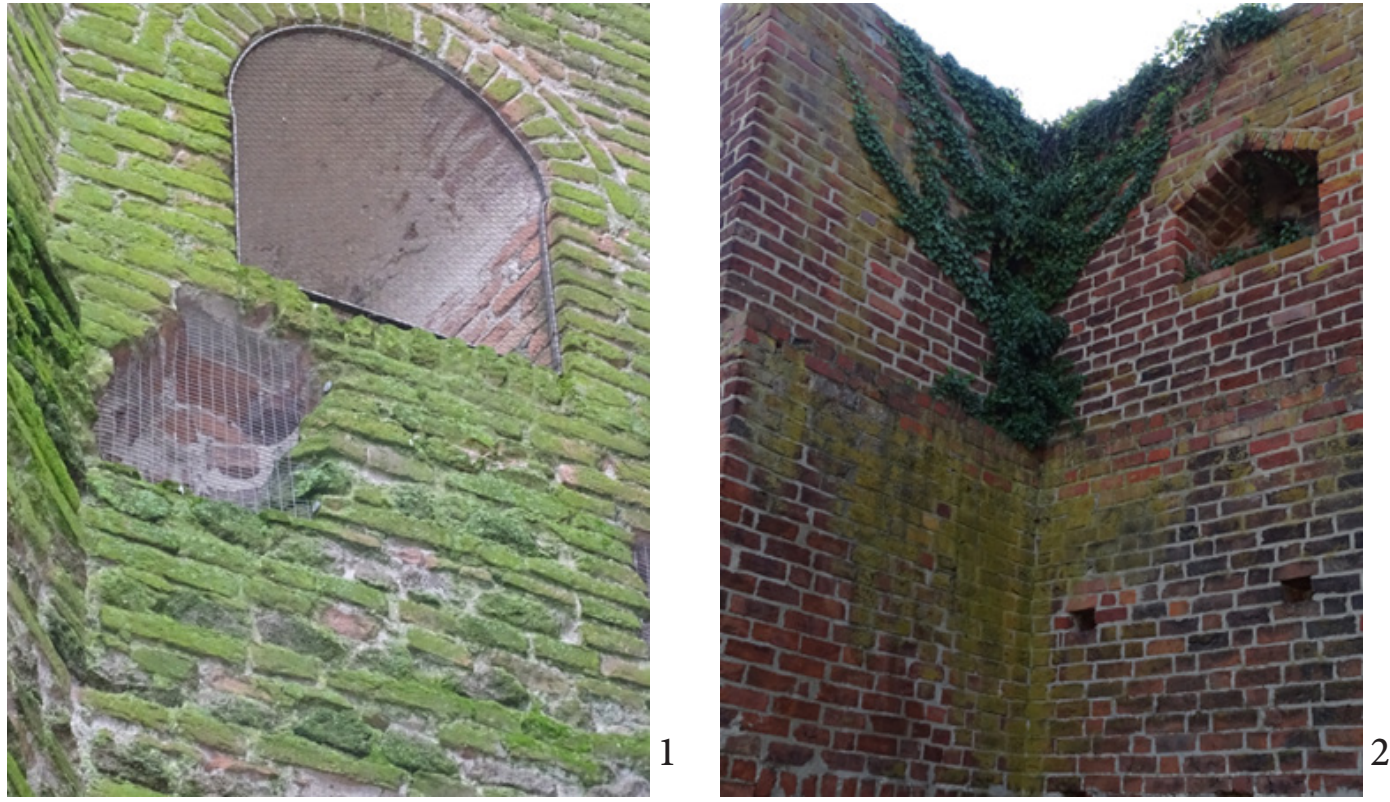

Ryc. 1 Kolonie glonów na przewilgoconym murze z cegły ceramicznej

Ryc. 2 Rozwój glonów i porostów w narożu muru bezpośrednio pod porastającym mur i koronę bluszczem
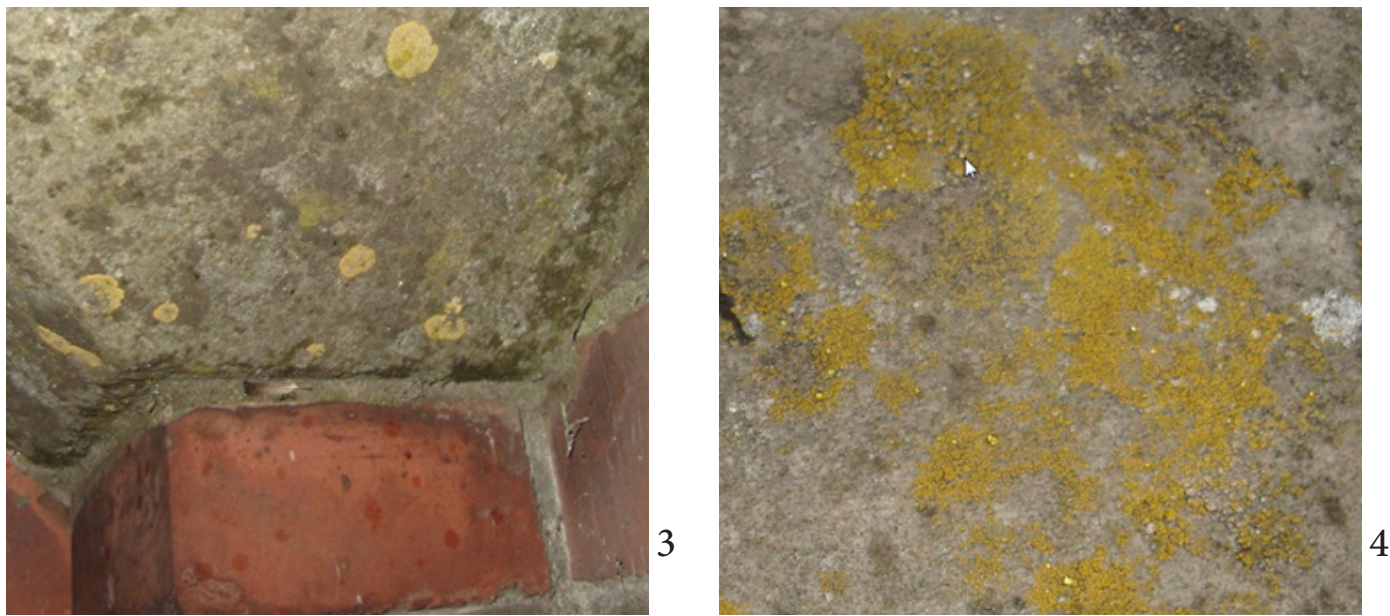

Ryc. 3 Porażony porostami fragment tynkowanego sklepienia

Ryc. 4 Kolonie porostów na historycznym tynku muru zewnętrznego obiektu

${ }^{6}$ S. Ferraby, The ecology of ruin sites [w:] Conservation of Ruins, ed. John Ashurst, Elsevier Science \& Technology, 2006, s. $209-210$. 
Korozja biologiczna i roślinność a trwała ruina
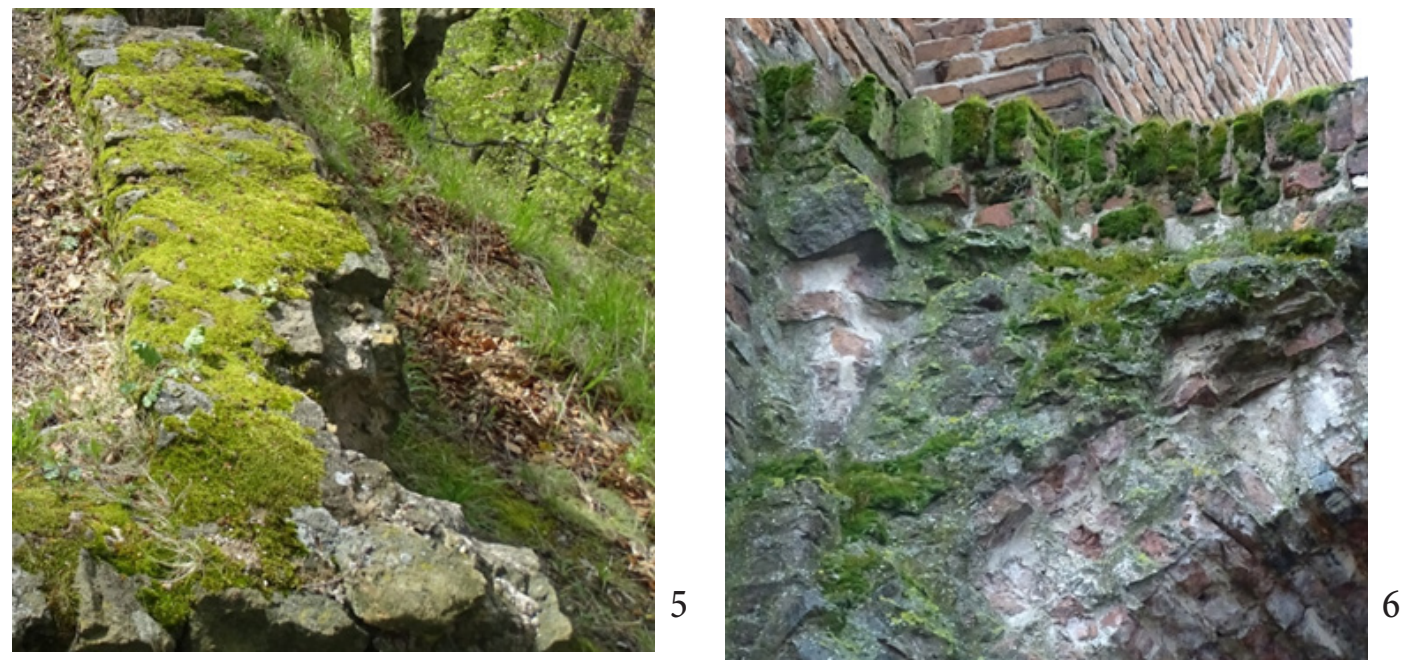

Ryc. 5 Mchy porastające niską koronę muru północnego ruiny

Ryc. 6 Porażenie mchami i glonami korony i lica muru

\subsection{Grupa II - uszkodzenia wgłębne lica i korony}

Druga grupa obejmuje uszkodzenia wgłębne warstw przypowierzchniowych muru /lica i korony/.Zniszczenia są powodowane przez niewielkie rośliny wykształcające system korzenny, a co za tym idzie wymagające odpowiedniego podłoża lub miejsca, w którym mogą wzrosnąć. Do grupy tej zaliczono wszystkie gatunki roślinności niskiej w obiektach w ruinie: trawy, byliny, bluszcze i sukulenty.

Rozwój roślin zielonych rozpoczyna się wraz z pojawieniem minimalnej ilości humusu w szczelinach i na koronie muru. Początkowo dominują przede wszystkim niewielkie rośliny jedno roczne i trawy. Z czasem wraz $\mathrm{z}$ przyrostem warstwy humusowej (rozkład roślin, nawiewanie gleby) pojawiają się rośliny wieloletnie. Wzrost ich jest szczególnie intensywny w miejscach gdzie utrzymuje się podwyższona wilgotność, jednak wiele gatunków jest w stanie zasiedlać fragmenty suche i mocno nasłonecznione.

Wzrost i rozkład roślinności powodują pojawianie się w murze kwasów humusowych oraz wzrost ilości azotanów. Kwasy powodują rozpuszczanie substancji wiążących w spoinach ich osłabienie, a w konsekwencji szereg uszkodzeń powierzchni lica. Wzrost stężenia azotanów odpowiada zakolejne uszkodzenia warstw przypowierzchniowych. Krystalizujące solezwiększają swoją objętość rozsadzając pory spoin i materiałów murowych. Ciśnienie krystalizacyjne jest na tyle wysokie, że do uszkodzeń dochodzi nawet w przypadku skał o dużej twardości.

Kolejnym skutkiem rozwoju roślinności niskiej są uszkodzenia na styku spoiny i materiału murowego związane z rozwojem systemu korzennego. Rozrastające się korzenie powodują uszkodzenia słabych /najczęściej wapiennych lub glinianych/ spoin, co prowadzić może do kolejnych uszkodzeń warstw lica/pojedynczych odspojeń drobnych kamieni lub całych fragmentów. 
Substancje chemiczne wydzielane przez roślinność oraz pochodzące z ich rozkładu wypływają również na przebarwienia powierzchni lica powodując negatywne efekty estetyczne.
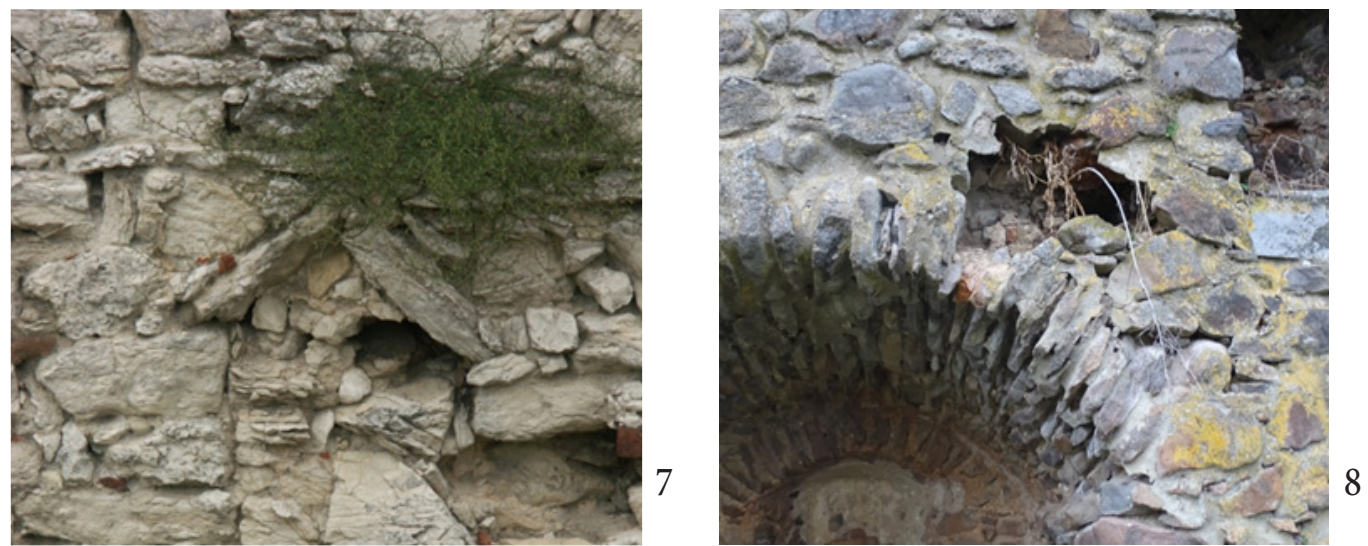

Ryc. 7 Fotografia mocno nasłonecznionej elewacji południowej. Rozwój roślinności w szczelinach muru

Ryc. 8 Uszkodzenie lica muru związane z rozrostem systemu korzeniowego roślinności niskiej
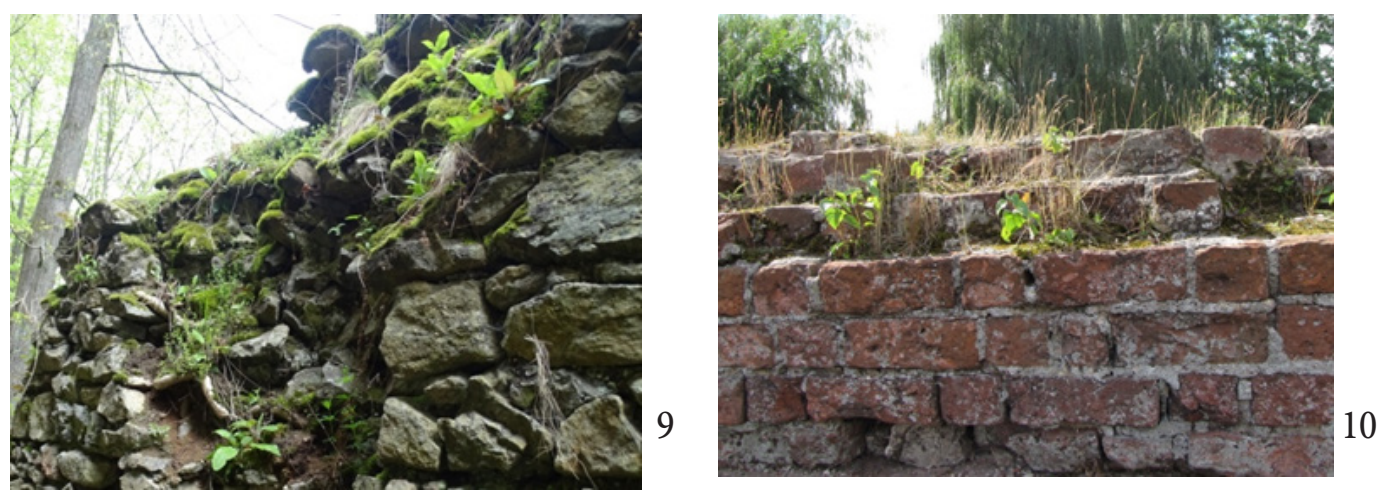

Ryc. 9 Porośnięte roślinnością jedno i wieloletnią korona i lico muru kurtynowego

Ryc. 10 Ekspansja roślin niskich i mchów na koronie muru z cegły ceramicznej. W pierwszym planie widoczne młode krzewy 
Korozja biologiczna i roślinność a trwała ruina $\square \square^{207}$
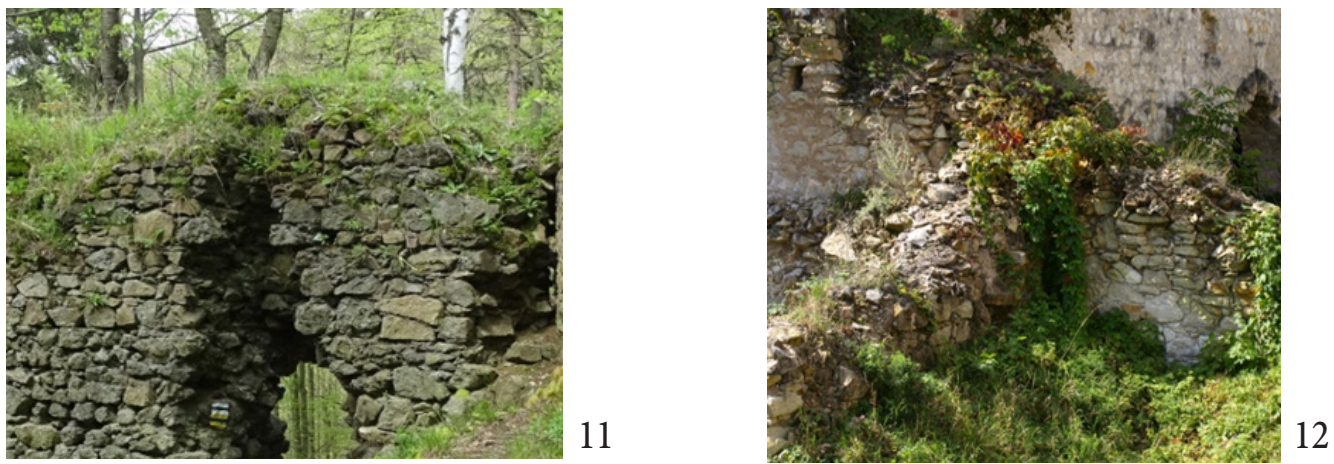

Ryc. 11 Całkowicie zarośnięta zielenią niską korona muru. Szczelna warstw humusu i zieleni uniemożliwia odparowywanie zatrzymanej w murze wilgoci

Ryc. 12 Porośnięty roślinnością relikt muru. Duża ilość zieleni powoduje nieczytelność ruiny

\subsection{Grupa III - uszkodzenia konstrukcji}

Trzecia grupa obejmuje wielkopowierzchniowe uszkodzenia lica i samej konstrukcji muru. Powodują je rośliny wieloletnie, których system korzenny jest bardzo rozbudowany i przerasta mury czy też sklepienia obiektu. Do trzeciej grupy zaliczono drzewa i krzewy.

Wpływ roślinności wysokiej na mury jest znacznie większy niż w przypadku pozostałych grup organizmów opisanych w poprzednich podrozdziałach. Podobnie jak one drzewa i krzewy oddziałują na substancję chemiczne. Korzenie wydzielają duże ilości kwasów organicznych powodujących rozkład węglanu wapnia w spoinach wątków murowych. Prowadzi to do osłabienia wiązań spoina-materiał murowy wewnątrz muru. Wraz z wodą związki te przemieszczają się do powierzchni, a następnie po odparowaniu wody krystalizują. Krystalizacja powoduje doszczelnienie przypowierzchniowych warstw oraz pojawienie się zacieków węglanowych.

Opadające liście zalegają w szczelinach i zagłębieniach muru, a po rozkładzie stanowią podłoże pod rozwój roślinności niskiej oraz mszaków. Dodatkowo wraz z wodą do wnętrza muru przedostają się duże ilości azotanów pochodzących z rozkładu liści.

Drzewa i krzewy oddziałują na ruinę również mechanicznie. Rozrastające się korzenie wypełniają szczeliny muru i powodują powstanie coraz to nowych pęknięć i odprysków powierzchniowych kamienia i cegły. Duże systemy korzenne przerastając mury z czasem mogą doprowadzić do wielko powierzchnio wych odspojeń lica oraz znacznych uszkodzeń konstrukcji całego muru.

Obecność wysokich drzew przerastających mury lub też w ich najbliższym otoczeniu może być również bardzo niebezpieczna podczas intensywnych burz lub silnie wiejących wiatrów. Wyrwane z korzeniami lub złamane może doprowadzić do istotnych zniszczeń ruiny lub też być zagrożeniem dla ludzi przebywających na obiekcie.

Stałe zacienienie muru przez roślinność wysoką utrudnia jego odsychanie co może doprowadzić do intensywnego rozwoju roślinności niskiej, glonów i mszaków. 

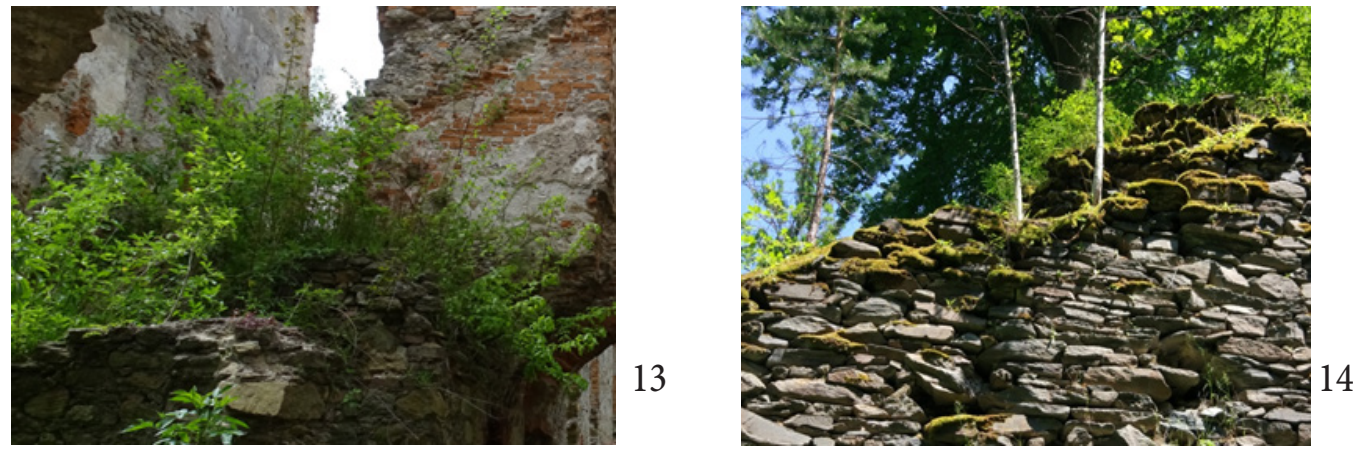

Ryc. 13 Fragment sklepienia intensywnie porośnięty krzewami

Ryc. 14 Mur kamienny z młodymi brzozami na koronie

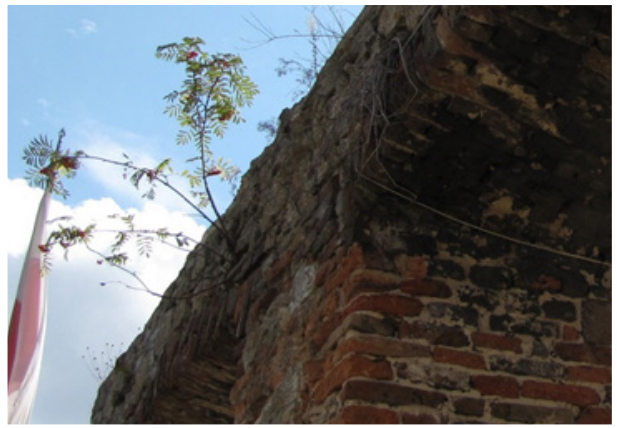

15

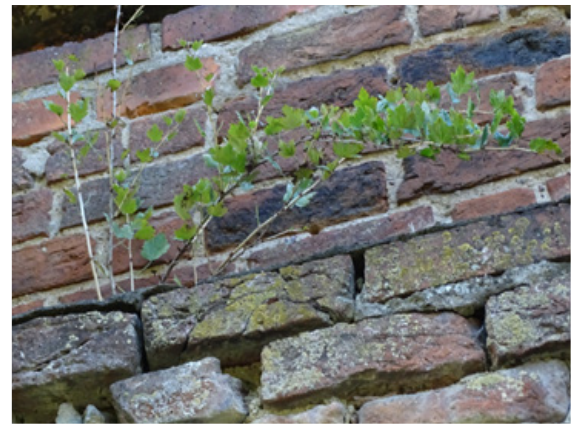

Ryc. 15 Jarzębina zakorzeniona w szczelinie pomiędzy murem korony i nadprożem Ryc. 16 Krzew z systemem korzennym przerastającym mur z cegły ceramicznej
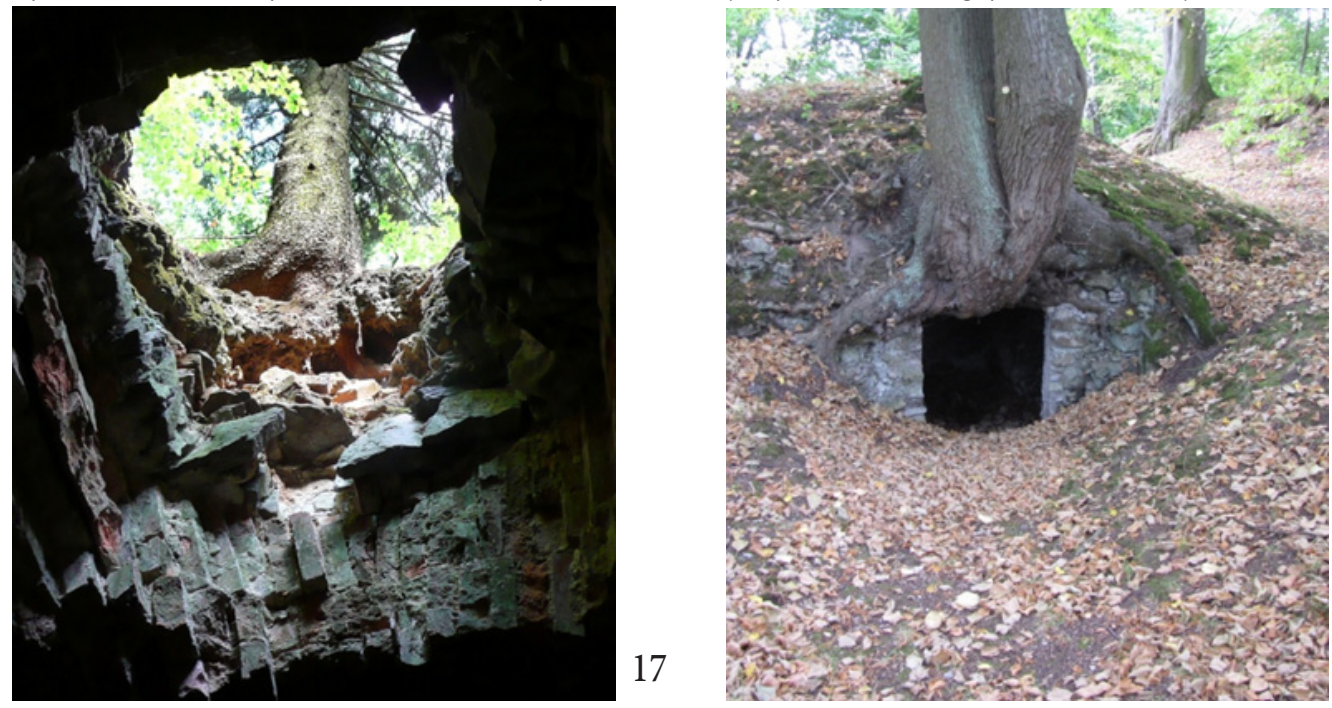

Ryc. 17 Uszkodzone przez korzenie sklepienie z cegły ceramicznej

Ryc. 18 Olbrzymie drzewo przerastające systemem korzennym sklepienie z kamienia 
Korozja biologiczna i roślinność a trwała ruina

\section{ZASADY POSTĘPOWANIA PRZY USUWANIU KOROZJI BIOLOGICZNEJ I ROŚLINNOŚCI}

Problemy dotyczące oddziaływania roślinnościna obiekty w trwałej ruinie jestzagadnieniem otwartym, którym zajmują się zarówno architekci, konserwatorzy jak i inżynierowie. W dużej liczbie publikacji naukowych i popularno-naukowych oddzielną grupę stanowią poradniki dla zarządców i opiekunów obiektów. ${ }^{7} 910$ Wytyczne w poradnikach wskazują na konieczność konsultacji ze specjalistami, przed rozpoczęciem jakichkolwiek działań dotyczących postępowania z roślinnością porastającą obiekty utrzymane w trwałej ruinie.

Usuwanie organizmów odpowiedzialnych za rozwój korozji biologicznej związane jest $\mathrm{z}$ koniecznością prowadzenia działań, które w sposób bezpośredni lub pośredni mogą wpływać na zachowanie samej ruiny. Ze względu na możliwość wystąpienia podczas tych prac niekorzystnych zmian: uszkodzenia konstrukcji, powierzchniowe zniszczenia lica, uszkodzenia detali, zmiana kolorystyki itp. usuwanie organizmów odpowiedzialnych za korozję podlegać powinno określonym zasadom. Ze względu na różnice związane z budową organizmów (brak lub istnienie systemów korzennych), miejscem występowania oraz rodzajem uszkodzeń spowodowanych działaniem organizmów zasady postępowania zebrane zostały $\mathrm{w}$ dwóch grupach.

Zasady postępowania przy usuwaniu glonów, mchów porostów i grzybów-pleśni

- Ustalenie czy występujące organizmy muszą być usunięte, czy też ich wpływ na materiał jest nieistotny i mogą pozostać.

- Określenie stopnia porażenia i rodzaju uszkodzeń.

- Przyjęcie metody usuwania organizmów. Metoda musi uwzględniać, powierzchnię poddaną pracom, dostępność, teksturę materiału, wytrzymałość przypowierzchniowych warstw oraz stopień porażenia.

- Przy mechanicznym usuwaniu koniecznym jest wykonanie prób skuteczności czyszczenia i wpływu użytej metody na podłoże.

- Stosowanie preparatów chemicznych zwalczających organizmy wymaga określenia wpływu substancji na oczyszczane powierzchnie. Związki zawarte w stosowanych substancjach nie mogą powodować zmian w strukturze, obniżać wytrzymałości czy też powodować zmian w kolorystyce.

7 J. Donnelly, Ruins: the Conservation and Repair of Masonry Ruins, Government Publications Sales Office, Dublin, 2010.

8 J. A. Eklund, M. E. Young, Biological Growth on Masonry: Identification \& Understanding. Inform. Information of historic building owners. Published by Historic Scotland, January 2013.

9 R. Fawcett, Treatment of vegetation at monuments [w:] The Conservation of Architectural Ancient Monuments in Scotland. Guidance on Principles. Published by Historic Scotland. Longmore House. Salisbury Place. Edinburgh 2001, s. 44-47.

10 P. Kozarski, P. Molski, Zagospodarowanie i konserwacja zabytkowych budowli. Towarzystwo Przyjaciół Fortyfikacji, Fortyfikacje tom XIV, Warszawa 2001. 
- Po wykonaniu prac oczyszczających przeprowadzenie dezynfekcji powierzchni muru. -Określenie po jakim czasie zabiegi wymagają powtórzenia.

Zasady postępowania przy usuwaniu roślinności niepożądanej

- Przed rozpoczęciem prac należy dokonać przeglądu stanu murów i określić miejsca, w których przeprowadzone zostaną prace.

- Ustalenie, które grupy roślin podlegać mają usunięciu, w określonych przypadkach może być podjęta decyzja o pozostawieniu niektórych roślin lub ich części (bluszcze, trawy porastające zabezpieczone korony murów).

- W przypadku konieczności prac prowadzonych na dużych wysokościach, szczególnie przy wycince drzew prac powinny być zlecone specjalistom.

- Rośliny jednoroczne i wieloletnie (trawy, byliny i chwasty) w miarę możliwości usuwać należy z całym systemem korzennym.

- Po wyrwaniu roślin z szczelin i zagłębień należy w miarę możliwości usuwać zalegające tam warstwy ziemi. Zabieg ten w przyszłości opóźni rozrost kolejnych organizmów.

- Przed wykorzystaniu preparatów chemicznych, każdorazowo należy określić ich wpływ na materiał ruiny.

- Stosowane środki chemiczne w obrębie ruiny nie mogą wpływać negatywnie na roślinność planowaną.

- Usuwanie wysokich drzew zarówno przy samych murach jak i tych z systemem korzennym przerastającym konstrukcję musi być poparte analizą wpływu wycinki na zachowanie murów.

- Nie zaleca się usuwania pni i korzeni po wycince drzew jeżeli wpływają one za stabilność skarp przy murach i stateczność samych murów.

- W przypadku usuwania drzew i krzewów istnieje konieczność uwzględnienia okresów lęgowych ptaków.

- Po przeprowadzeniu prac oczyszczających ruinę z zieleni niepożądanej zaleca się okresowe monitorowanie murów i prowadzenie prac zapobiegających zarastaniu.

\section{PODSUMOWANIE}

Rozwój organizmów na murach obiektów zabezpieczonych w postaci trwałej ruiny jest procesem nieuniknionym. Specyfika tych budowli /obiekty niezadaszone, nieogrzewane, a często nieużytkowane i pozbawione opieki/ powoduje, że w sprzyjających warunkach jakie tam panują organizmy będę się rozwijały zawsze. Ważnym jest aby rozwój ten nie miał charakteru niekontrolowanego. Pozbawienie murów opieki na zaledwie kilka lat doprowadzić może do szeregu zniszczeń często o charakterze nieodwracalnym.

Dlatego kluczowym jest aby obiekty takie poddawane były okresowym przeglądom, pozwalającym na prowadzenie prac oczyszczających w momencie w którym dochodzi do 
Korozja biologiczna i roślinność a trwała ruina $\square \square^{211}$

porażenia korozją czy też rozrostu roślinności. Właściwie przeprowadzony przegląd pozwala na podjęcie decyzji, które gatunki i egzemplarze powinny być natychmiast usunięte, a które pozostawione i traktowane jako element aranżacji. Cyklicznie prowadzone działania nie pozwolą na nadmierny rozrost szaty roślinnej oraz obniżą koszty działań związanych $\mathrm{z}$ usuwaniem roślinności. 


\section{Literatura}

1. Building Research Establishment. Control of lichens, moulds and similar growths. Garston, Watford: Building Research Establishment, 1992.

2. Donnelly J., Ruins: the Conservation and Repair of Masonry Ruins, Government Publications Sales Office, Dublin, 2010

3. Eklund J. A., Young M. E., Biological Growth on Masonry: Identification \&Understanding. Inform. Information of historic building owners. Published by Historic Scotland, January 2013

4. Fawcett R., Treatment of vegetation at monuments [w:] The Conservation of Architectural Ancient Monuments in Scotland. Guidance on Principles. Published by Historic Scotland. Longmore House. Salisbury Place. Edinburgh 2001, s. 44-47.

5. Ferraby S., The ecology of ruin sites [w:] Conservation of Ruins, ed. John Ashurst, Elsevier Science \& Technology, 2006, s. $209-210$

6. Further Reading and Contacts Biological Growths on Sandstone Buildings: Control \& Treatment, Technical, Advice \& Guidance, Technical Advice Notes, Historic Scotland, tom 10, 1997.

7. Gordon R., Biological Growths, Biocide Treatment, Soiling and Decay of Sandstone Buildings and Monuments in Scotland. Report on research commissioned. Historic Scotland and The Robert Gordon University, 1995.

8. Jasieńko J., Mierzejewska O., Hamrol K., Misztal W., Utrwalanie koron murów obiektów historycznych przeznaczonych do ekspozycji w formie trwałej ruiny, Wiadomości konserwatorskie nr 30, 2011, s. 117-132

9. Kozarski P., Molski P., Zagospodarowanie i konserwacja zabytkowych budowli. Towarzystwo Przyjaciół Fortyfikacji, Fortyfikacje tom XIV, Warszawa 2001

10. Praca zbiorowa pod redakcją Ważnego J., Karysia J., Ochrona budynków przed korozja biologiczna Arkady, Warszawa 2001.

11. Quinlan M., Hanna M., Kelly D., The conservation and repair of masonry ruins, Government of Ireland, Dublin, 2010

12. Sieniawska-Kuras A, Potocki P., Przyczyny zniszczeń obiektów budowlanych i elementów architektonicznych. Procesy biologiczne. [w:] Renowacja elementów architektury. Wydawnictwo i handel książkami „KaBe”, Krosno 2012, s. 53-55

13. Strzelczyk A. B., Czynniki niszczace kamienie. Czynniki biologiczne, [w:] Zabytki kamienne i metalowe ich niszczenie i konserwacja profilaktyczna, red. Wiesław Domasłowski. Wydawnictwo Naukowe UMK, Toruń 2011, s.135-157

14. Tajchman J., Metoda zabezpieczania i rewitalizacji ruin historycznych jako szczególny rodzaj konserwacji $i$ restauracji zabytków architektury, Materiały z międzynarodowej konferencji naukowej, Gubin 2008.

15. Trochonowicz M., Zamek w Janowcu nad Wisła. Ocena stanu wilgotnościowego i zasolenia murów. Politechnika Lubelska, Lublin 2006.

16. Young M., Wakefield R., Research commission investigating biological growths, biocide treatment soiling and decay of sandstone buildings and monuments in Scotland. 1995 